
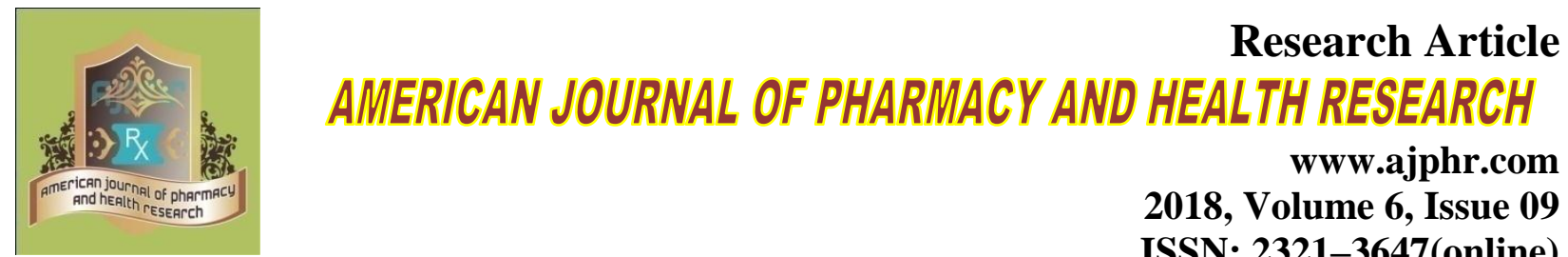

www.ajphr.com

2018, Volume 6, Issue 09

ISSN: 2321-3647(online)

\title{
In Vitro Anti Cancer Activity of Ethanolic Extract of Eclipta Alba
}

(L.)

Y. Anil Kumar*1, Konda Ravi Kumar', Y. Sirisha ${ }^{3}$, B. Gopikrishna ${ }^{3}$, S. Yashita raga ${ }^{3}$. 1.Department of Pharmacology, Hindu College of Pharmacy, Amaravthi road, Guntur.

2.Department of Pharmaceutical Chemistry, Hindu College of Pharmacy, Amaravthi road, Guntur.

3.Department of Pharmaceutical Analysis, SIMS College of Pharmacy, Mangaldas Nagar,

Guntur.

\begin{abstract}
Cancer is a group of diseases involving uncontrolled and abnormal growth of cells with potential to invade (or) spread to other parts of body. The aim of present study is to evaluate the invitro anti cancer screening of ethanolic extract of whole plant of Eclipta alba against HL-60 cell lines by SRB (sulphorhodamine) assay, besides this property it has many other therapeutic uses. The plant with methanol is kept in closed vessel for seven days and the obtained extract is subjected to preliminary phytochemical analysis and in vitro anti cancer screening, these test reveals the presence of secondary metabolites and $\mathrm{LD}_{50}$ concentration of extract was $>80 \mu \mathrm{g} / \mathrm{ml}$ respectively i.e) the extract can inhibit the growth of cancer cells rather than killing them. For killing the cancerous cells very high concentration of extract is required.
\end{abstract}

Key words: Eclipta alba, Anti-cancer activity, SRB assay, HL-60 cell lines.

*Corresponding Author Email: anilkumar.yerragopu@gmail.com Received 29 August 2018, Accepted 06 September 2018

Please cite this article as: Kumar A et al., In Vitro Anti Cancer Activity of Ethanolic Extract of Eclipta Alba (L.). American Journal of Pharmacy \& Health Research 2018. 


\section{INTRODUCTION}

Eclipta alba [L] is an annual herbaceous plant, commonly known as false daisy. It is an erect (or) prostrate, much branched, roughly hairy, rooting at the nodes, the leaves are opposite, sessile and lanceolate. It is also known as Bhringaraj and Karisilakanni. The genus name comes from the Greek word meaning "Defeceint", with reference to the absence of the bristles and owns on the fruits. Main active principles consist of coumestans like wedelolactone, dimethyl wedelolactone, furanocoumarins, olenane and taraxastane glycosides. It is adaptable to changing habitat and also found in some temperate parts of the world, prefers warm climate at a temperature range of 25 $35^{\circ} \mathrm{C}$ for its good growth and yield. It is a cosmopolitan weed by western colonization activity (Duthie, 1905). Eclipta is said to be the best drug for the treatment of liver ailments such as cirrhosis, infective hepatitis and other conditions involving hepatic enlargement. Medicinal value of Bhringraj has been discussed in the "Bhavaprakash"- the ancient Indian classic fresh juice of leaves is rubbed on the scalp for promoting growth of hair. Bhringraj is bitter, hot fattening alterative anthelminticum and alexipharmic. It is useful in mental disorders, anaemia, headaches, earaches, insomnia, dysentery, fevers and as a mild laxative ${ }^{[1-3]}$. Bhringraj works as an antiseptic, astringent, oral mouthwash for infected gums and loose teeth. It also helps to maintain and rejuvenate teeth, bones, sight, hearing and memory. Externally it can also use or minor cuts or injuries, athlete foot, eczema.

\section{Scientific Classification}

It belongs to Kingdom of Plantae, Clade of Angiosperms, Asteraceae ${ }^{[4]}$ family. Its genus is Eclipta and species is alba. Its binomial name is Eclipta alba L.

Eclipta alba is geographically distributed in Himalayas, in moist and cool places of Punjab, Orissa, Bihar, West and south India. ${ }^{[5]}$ Eclipta alba has antihepatotoxic properties- it significantly counteracted CC14-induced inhibition of hepatic microsomal drug metabolising enzymes ${ }^{[6]}$, immunomodulatory activities, analgesic and anti-inflammatory activity ${ }^{[7]}$, anti-diabetic, anticancer $^{[8]}$, anti hyperlipedemic properties ${ }^{[9]}$, anti oxidant properties ${ }^{[10]}$,anti microbial activity, miscellaneous activity.

\section{MATERIALS AND METHOD}

The plant material Eclipta alba was collected from the botanical gardens of Andhra university, Visakhapatnam, India in august 2017. The plant species was authenticated by Dr.M.Ramaiah, Associate professor and Head, Department of pharmacognosy, Hindu College of Pharmacy, Guntur, India. 


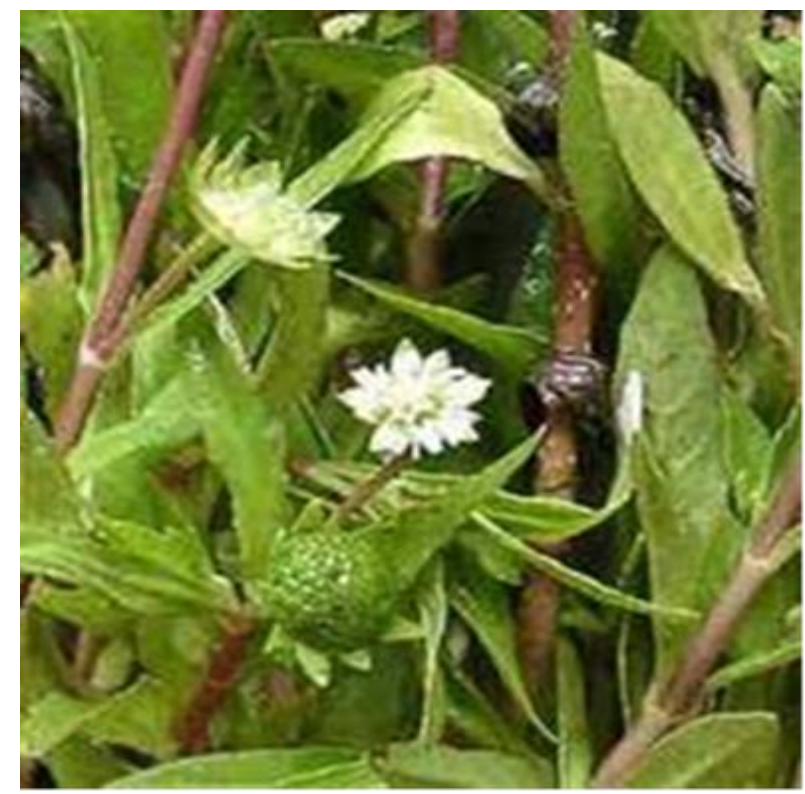

Figure 1: Diagram of Eclipta alba plant

\section{Extraction Process}

The dried powdered plant material (1000gms) was allowed to contact with solvent methanol in a closed vessel and then allowed to macerate with occasional shacking for seven days. Strain the liquid, press the marc, mix the liquids and finally clarifying by filtration. The extract thus obtained was concentrated under vacuum $\left(50^{\circ} \mathrm{C}\right)$ by using rotary evaporator, dried completely and weighed. The extract thus collected was subjected to preliminary phytochemical analysis and invitro anticancer screening. (Yield $=52.24 \%$ )

\section{Preliminary Phytochemical Analysis}

The extract was prepared and tested for preliminary phytochemical analysis which is used to identify the presence of various secondary metabolite. Identified secondary metabolites are carbohydrates, proteins \& amino acids, steroids and triterpenoids, glycosides, flavonoids, tannins, etc, are given in Table1.

Table 1: Phytochemical analysis of Ethanolic Plant extract

\begin{tabular}{lll}
\hline S. No. & Compound & Ethanolic Extract \\
\hline 1. & Carbohydrates & + \\
2. & Proteins \& amino acids & + \\
3. & Steroids \&Triterpenoids & + \\
4. & Glycosides & + \\
5. & Flavonoids & + \\
6. & Alkaloids & - \\
7. & Tannins & + \\
8. & Saponins & - \\
\hline \multicolumn{4}{c}{ '+'Present, '-' Absent }
\end{tabular}




\section{In-Vitro Anticancer Screening against HL-60 Cell lines}

Crude methanolic plant extract was prepared by cold maceration technique and then further extract was subjected to preliminary phytochemical studies and in-vitro anticancer screening by SRB assay.

\section{Chemicals}

Test drugs: Ethanolic extract of Eclipta alba (at 10, 20, 40 and $80 \mu \mathrm{g} / \mathrm{ml}$ doses) mentioned in Table 2. 
Table 2: \% Control Growth of Ethanolic extract of Eclipta alba on HL60 cell lines

\begin{tabular}{|c|c|c|c|c|c|c|c|c|c|c|c|c|c|c|c|c|}
\hline \multicolumn{17}{|c|}{ Human Leukemia Cell Line HL60 } \\
\hline \multicolumn{17}{|c|}{ Drug Concentrations $(\mu \mathrm{g} / \mathrm{ml})$} \\
\hline & \multicolumn{4}{|c|}{ Trail- I } & \multicolumn{4}{|c|}{ Trail- II } & \multicolumn{4}{|c|}{ Trail- III } & \multicolumn{4}{|c|}{ Average Value } \\
\hline & $\mathbf{1 0} \mu \mathrm{g} /$ & 20 & 40 & 80 & $\mathbf{1 0} \mu \mathrm{g} /$ & 20 & 40 & 80 & $\mathbf{1 0} \mu \mathrm{g} /$ & 20 & 40 & 80 & $\mathbf{1 0} \mu \mathrm{g} /$ & 20 & 40 & 80 \\
\hline & $\mathrm{Ml}$ & $\mu \mathrm{g} /$ & $\mu \mathrm{g} /$ & $\mu \mathrm{g} /$ & $\mathrm{ml}$ & $\mu \mathrm{g} /$ & $\mu \mathrm{g} /$ & $\mu \mathrm{g} /$ & $\mathrm{ml}$ & $\mu \mathrm{g} /$ & $\mu \mathrm{g} /$ & $\mu \mathrm{g} /$ & $\mathrm{ml}$ & $\mu \mathrm{g} /$ & $\mu \mathrm{g} /$ & $\mu \mathrm{g} /$ \\
\hline & & $\mathrm{ml}$ & $\mathrm{ml}$ & $\mathrm{ml}$ & & $\mathrm{ml}$ & $\mathrm{ml}$ & $\mathrm{ml}$ & & $\mathrm{ml}$ & $\mathrm{ml}$ & $\mathrm{ml}$ & & $\mathrm{ml}$ & $\mathrm{ml}$ & $\mathrm{ml}$ \\
\hline EEEA & 97.9 & 52.1 & 15.0 & 4.5 & 94.3 & 55.1 & 13.8 & 2.7 & 81.0 & 50.5 & 16.6 & 5.9 & 91.1 & 52.6 & 15.2 & 4.4 \\
\hline ADR & -7.3 & -31.3 & -46.6 & -49.0 & -4.7 & -34.5 & -34.5 & -41.7 & 1.6 & -12.7 & -17.4 & -26.8 & -3.5 & -26.2 & -32.8 & -39.2 \\
\hline
\end{tabular}




\section{Standard drug: Adriamycin}

Cell lines: human leukemia cell lines (HL60 cell lines)

Cell culture: Human Leukemia Cell lines (HL60 cell lines) used in this study were procured from Advanced Centre for Treatment Research and Education in Cancer (ACTREC), Mumbai. All cells were grown in Minimal essential medium (MEM, GIBCO) supplemented with $4.5 \mathrm{~g} / \mathrm{L}$ glucose, 2 $\mathrm{mM}$ L-glutamine and $5 \%$ fetal bovine serum (FBS) (growth medium) at $37^{\circ} \mathrm{C}$ in $5 \% \quad \mathrm{CO}_{2}$ incubator. Photomicrographs of growth morphology of Human Leukemia Cell Line HL60 was shown in Figure 2.

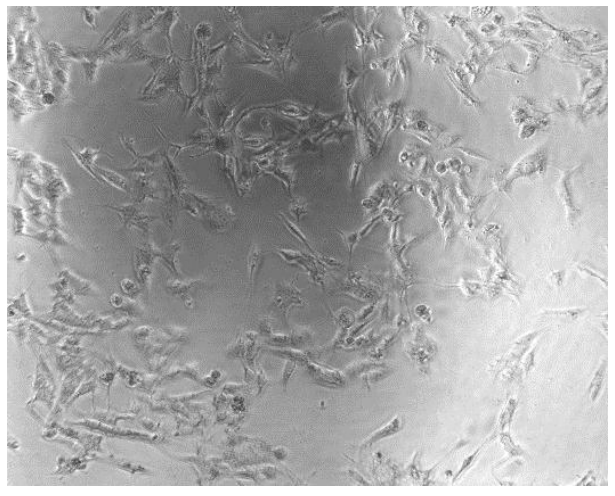

STANDARD

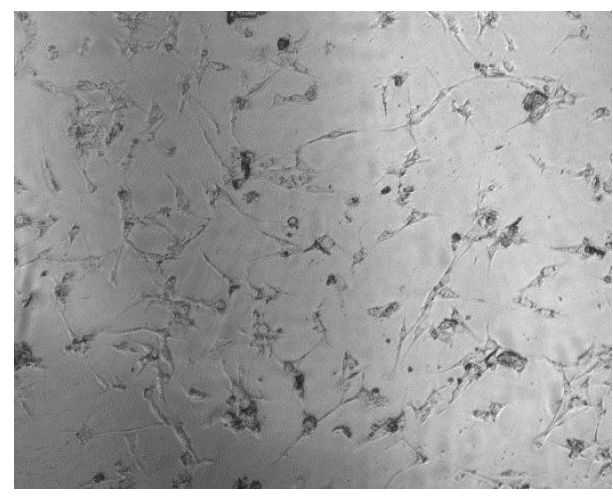

SAMPLE

Figure 2: Photomicrographs of growth morphology of Human

\section{Leukemia Cell Line HL60 (Standard \& Sample)}

\section{Sulphorhodamine (SRB) assay ${ }^{[11]}$}

The monolayer cell culture was trypsinized and the cell culture was adjusted to $5 \times 10^{3} \mathrm{cell} / \mathrm{ml}$. To each well of the 96 well microtiter plate, $0.1 \mathrm{ml}$ of the diluted cell suspension was added. After $24 \mathrm{hrs}$, when a partial monolayer had formed. Supernatant was flicked off, the monolayer was washed once with medium and $100 \mu \mathrm{l}$ of different concentrations of extract were added to the cells in microtiter plates. The plates were then incubated at $37^{\circ} \mathrm{C}$ for 3 days in $5 \% \mathrm{CO}_{2}$ atmosphere, microscopic examination was carried out and observations were recorded every $24 \mathrm{hr}$. After 72 hrs, $25 \mu \mathrm{l}$ of $50 \%$ TCA (Trichloroacetic acid) was gently added to the wells in such a way that it formed a thin- layer over the extract. The plates were incubated at $4^{\circ} \mathrm{C}$ for $1 \mathrm{hr}$. They were flicked and washed 5 times with water to remove traces of the medium, extract and serum and air dried. They were stained with SRB $(0.4 \%$ prepared in $1 \%$ acetic acid $)$ for 30 mins. The unbound dye was then removed by rapidly washing 4 times with $1 \%$ acetic acid. The plates were then air dried. Tris base [tris (hydroxymethyl) aminomethane] $(10 \mathrm{mM}, 100 \mu \mathrm{l})$ was then added to the wells to solubilize the dye. The plates were shaken vigorously for $5 \mathrm{~min}$. The absorbance was measured 
using a micro plate reader at a wavelength of 540nm. The percentage control growth, GI50 (conc. of drug or test extract needed to inhibit cell growth by 50\%), TGI and LC 50 were calculated from dose response curves for each cell line.

\section{RESULTS AND DISCUSSION}

Anticancer activity of ethanolic extract of Eclipta alba was conducted with appropriate positive control (Adriamycin) which yielded results on HL60 cell lines. The extract shows good inhibitory activity but the inhibitory effect of this extract was observed to be a little bit weaker than that shown by standard drug Adriamycin. The results were shown in the Table 3.

Table 3: LC50, TGI and GI50 Drug concentrations $(\mu \mathrm{g} / \mathrm{ml})$ of Ethanolic extract of Eclipta alba on HL60 cell lines

\begin{tabular}{|c|c|c|c|}
\hline \multirow[t]{2}{*}{ Name of the extract } & \multicolumn{3}{|c|}{ Drug concentrations $(\mu \mathrm{g} / \mathrm{ml})$ calculated from graph } \\
\hline & LC50 & TGI & GI50 \\
\hline EEEA & $>80$ & 70.2 & 30.5 \\
\hline ADR & 71.1 & 30.7 & $<10$ \\
\hline
\end{tabular}

From the results, it is clear that $\mathrm{LD}_{50}$ concentration of extract was greater than $80 \mu \mathrm{g} / \mathrm{ml}$ i.e, the extract is more preferably inhibiting the growth of cancer cells rather than killing the cells as the extract requires very high concentration to kill the cancerous cells. The ethanolic extract of Eclipta alba showed total growth inhibition at $30.5 \mu \mathrm{g} / \mathrm{ml}$ against HL 60 cell lines.

If GI 50 value of extracts is $\leq 20 \mu \mathrm{g} / \mathrm{ml}$ then it is considered to possess the anticancer activity. Here ethanolic extract of Eclipta alba showed result i.e., $30.5 \mu \mathrm{g} / \mathrm{ml}$ so it is considered as inactive on cancerous stem cells, but at the same time it was proved that a minimum of $40 \mu \mathrm{g} / \mathrm{ml}$ concentration is sufficient to produce GI 50. Therefore, from the above results it was clear that the plant Eclipta alba was having cytotoxic activity against the HL-60 cell lines and supports the folkloric usage of the plant and confirmed that the studied plant possesses the constituents (steroids, flavonoids, glycosides, carbohydrates and tannins) with cytotoxic properties that can be used for developing novel anticancer agents.

GI50: Growth inhibition of $50 \%$ (GI50) calculated from [(Ti-Tz)/(C-Tz)] x $100=50$, drug concentration resulting in a $50 \%$ reduction in the net protein increase

TGI: Drug concentration resulting in total growth inhibition (TGI) will calculate from $\mathrm{Ti}=\mathrm{Tz}$

LC50: Concentration of drug resulting in a 50\% reduction in the measured protein at the end of the drug treatment as compared to that at the beginning) indicating a net loss of $50 \%$ cells following treatment is calculated from $[(\mathrm{Ti}-\mathrm{Tz}) / \mathrm{Tz}] \times 100=-50$. 
ADR: Adriamycin (Doxorubicin), Positive control compound.

GI50 value of $\leq 10^{\wedge}$ - 6 (i.e. $1 \mu$ mole) or $\leq 10 \mu \mathrm{g} / \mathrm{ml}$ is considered to demonstrate activity in case of pure compounds. For extracts, GI50 value $\leq 20 \mu \mathrm{g} / \mathrm{ml}$ is considered to demonstrate activity.

EEEA: Ethanolic extract of Eclipta alba.

\section{CONCLUSION}

In vitro anticancer screening of ethanolic extract of whole plant of Eclipta alba against HL-60 cell lines by Sulphorhodamine (SRB) assay reveals that the plant having cytotoxic activity against the HL-60 cell lines and supports the folkloric usage of the plant. Preliminary phytochemical analysis of methanolic extract of methanolic extract of whole plant of Eclipta alba reveals the presence of steroids, flavonoids, glycosides, carbohydrates and tannins. The presence of above constituents in alone or in combination might be responsible for the observed anticancer activity.

\section{REFERENCES}

1. Seru G, Maddi R, Kanuri Y. Standardization, qualitative-quantitative analysis and in vitro antioxidant capacity of methanolic extract of Begonia laciniataRoxb. Roots, International Journal of Pharmaceutical and Phytopharmacological Research, (2013); 3 (1): 74-78.

2. Davidson-HuntI. Ecologicalethnobotany: stumbling toward new practices and paradigm MASAJ. 2000;1-13

3. Harborne JB (1998). Phytochemical methods - A guide to modern techniques of plant analysis, 3rd Edition, Chapman \& Hall

4. .https://en.wikipedia.org/wiki/eclipta-prostrata.

5. Shodhgana.inflibnet.ac.in/bistream/10603/1186/11/11-chapter 205.

6. Saxena AK, Singh B, Anand KK. Hepatoprotective effects of Eclipta alba on subcellular levels in rats. Journal of ethnopharmacology. 1993; 40(3): 155-61

7. Arunachalam G, Subramanian N, Pazhani GP, Ravichandran V, Anti-inflammatory activity of methanolic extract of Ecliptaprostrata L.(Astearaceae). African Journal of Pharmacy and Pharmacology. 2009; 3(3): 97-100.

8. Malaya Gupta, UpalK.antiMazumdera, Palla K. Haldar, Chandi C. Kandar, LaxmananManikanda, G. P. Senthil. Anticancer Activity of Indigoferaas palathoides and Wedeliacalendulaceae in Swiss Albino Mice. Iranian journal of pharmaceutical research. 2005; 6(2): 141-45.

9. Dhandapani R. Hypolipidemic activity of Eclipta prostrata (L.) L. leaf extract in atherogenic diet induced hyperlipidemic rats. 2007; 45: 617-19. 
10. Dae-IkKima, Sung-Hyen Lee, Jin-Ho Choia, Hyun Soon Lillehoj, Mi-Hee Yu, Gun-Soon Lee. The butanol fraction of Ecliptaprostrata (Linn) effectively reduces serum lipid levels and improves antioxidant activities in CD rats. Nutrition Research. 2008; 28: 550- 54.

11. M. Srikanth, B. Ganga Rao and T. Mallikarjuna Rao (2013). Anticancer activity of various extracts of Musa rosacea, Avicennia marina and Bombexceiba, International Journal of Pharmacy and Pharmaceutical Sciences, 5(4):552-553.

AJPHR is

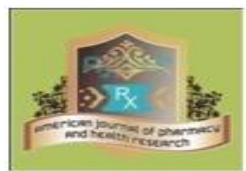

Peer-reviewed

monthly

Rapid publication

Submit your next manuscript at editor@ajphr.com / editor.ajphr@gmail.com 